\title{
Ciência, pandemia e lockdown: o lugar vago da Sociologia
}

\author{
Science, pandemic and lockdown: the vacant place of \\ sociology
}

\author{
Ciencia, pandemia y lockdown: el lugar vacante \\ de la sociologia
}

Recebido em 22-06-2021

Modificado em 27-07-2021

Aceito para publicação em 28-08-2021

\section{doi) https://doi.org/10.47456/simbitica.v8i3.36811}

\section{Marcos Lacerda}

Pós-doutorando em sociologia pelo Programa de Pós-graduação em Sociologia da Universidade Federal de Pelotas, Brasil. Núcleo de Interseccionalidades (PPGS/UFPel). Bolsista CAPES. E-mail:

lacerda.marcos81@gmail.com

\section{Léo Peixoto Rodrigues}

Licenciatura em Ciências Físicas e Biológicas pela Faculdade Porto Alegrense de Ciências e Letras (FAPA-RS); Pós-doutorado em Sociologia (UnB); Doutor em Sociologia (UFRGS); Prof. Associado do Instituto de Filosofia, Sociologia e Ciência Política e dos programas de Pós-Graduação em Sociologia e em Ciência Política da UFPel. E-mail: leo.peixotto@gmail.com

\section{Everton Garcia da Costa}

Doutor em Sociologia pela Universidade Federal do Rio Grande do Sul, Brasil. Mestre em Ciências Sociais e Licenciado em Letras pela UFPel. Email: eve.garcia.costa@gmail.com

\section{Resumo}

Paralelamente às milhões de vidas que ceifou em todo o planeta e às inúmeras consequências trazidas às diferentes esferas da vida social, a pandemia de Covid-19 trouxe à tona também uma série de debates de ordem moral, ideológica, cultural e social. As orientações biomédicas para tentar conter o avanço do coronavírus, principalmente o isolamento social, geraram um grande tensionamento em torno de algumas questões altamente complexas, como por exemplo, entre o compromisso com a coletividade versus a liberdade individual, o direito de viver a vida versus a defesa irrestrita da vida, as necessidades econômicas versus a manutenção da saúde. O objetivo deste artigo, justamente, foi o de refletir sobre essas questões, procurando problematizar o lugar da Sociologia - como campo do conhecimento científico - no interior desse debate.

Palavras-chave: pandemia de Covid-19; isolamento social; ciência; sociologia. 


\section{Introdução}

Existe uma importante discussão nas ciências biomédicas que questiona se um vírus tem ou não "vida". Afinal, trata-se de uma forma de vida, ainda que com uma constituição diferente do que se entende por "vida", ou ao contrário, o vírus é alguma coisa que fica no limiar entre seres animados e inanimados, e só vive efetivamente quando se une e parasita outros seres, estes sim, vivos? Parasita de tal modo, aliás, que precisa ser eliminado, ou "morto", para que o infeliz hospedeiro possa seguir com a sua vida.

A movimentação macabra e violentamente transnacional do vírus causador da Covid 19 vem devastando continentes e países continentais, começando pela China, primeiro epicentro e lócus inicial da pandemia, passando pela Europa, América Latina, Estados Unidos, até chegar ao Brasil. Na verdade, o vírus permanece muito "vivo", ou melhor, atuante em todo o mundo, com mudanças no seu grau de intensidade e morticínio, e sofrendo mutações constantes - as famigeradas cepas "variantes".

Surgido, ao que tudo indica, dos corpos de animais não-humanos, o Sars-Cov-2 tornou-se força avassaladora ao se instaurar nos corpos humanos, ao se imiscuir nos ambientes urbanos construídos por seres humanos, em aviões, trens, ônibus, casas, escritórios, supermercados, lojas e comércios em geral, galerias de arte, instituições de ensino, bares, restaurantes, enfim, em todos os lugares em que possa se alojar e se espraiar, desde que tenha seres humanos à espreita. O corpo humano é o seu habitat, o lugar mais valorado.

Com a pandemia, essa estranha forma de "existência", que não se sabe se de fato se é viva ou não, vem desordenando sistemas políticos, administrativos, econômicos, tencionando os sentidos e os limites da vida social, exigindo da sociologia contemporânea uma atenção maior para questões como as que envolvem as ciências biomédicas, a própria objetividade científica, conduzindo a uma impressionante revaloração, nos melhores casos, da racionalidade moderna e da transparência na esfera pública como condição de possibilidade para a solidariedade social.

Se por um lado os preceitos biomédicos são relevantes num contexto de pandemia, por outro, eles acabam por exigir o sacrifício, digamos assim, de ações comuns, que nos humanizam, tais como a presença no espaço público, as interações em bares, teatros, cinemas, casas de show; os encontros familiares; as reuniões entre amigos, em suma, o que costumamos chamar de "vida social”. Mas se há parcelas do humano a sacrificar, por conta da pandemia, há também para alguns, parcelas de humanos a sacrificar para que essa vida social seja mantida. A pandemia trouxe à baila discursos e, mesmo práticas político-institucionais, que se imaginavam superados, como os que falam abertamente em tons eugênicos, vendo na crise uma oportunidade de eliminar 
segmentos da sociedade que seriam considerados descartáveis. E isso, independente de marcadores sociais. Uma conhecida liderança da extrema direita brasileira afirmou, sem pestanejar, que de fato deveríamos pensar em selecionar pessoas que precisariam ser deixadas ao léu das intempéries da doença, sendo esses indivíduos os mais idosos, abrindo assim "espaço" numa forma de raciocínio macabra - aos mais jovens.

Se a problemática conceitual da definição do vírus pode nos conduzir a difíceis discussões de ordem moral, normativa e, mesmo, metafísica, todas conversando em alguma medida com a racionalidade científica dos saberes biomédicos, o seu efeito social, político e econômico nos parece o lugar mais adequado para uma análise sociológica relevante. E, entre a miríade de questões relacionadas, chama a atenção uma em especial: a que busca pensar as responsabilidades sociais, morais, políticas, econômicas, até mesmo criminais, dos atores sociais envolvidos na trama. Só que a responsabilidade social mais propriamente vinculada ao respeito às medidas sanitárias, especialmente aquelas associadas ao isolamento social.

Trataremos disso nas três partes desse artigo. A primeira voltada para situar a difícil relação entre consenso biomédico e racionalização da conduta social, tendo em vista as diferentes dimensões que conferem sentido à ação social e à constituição da conduta dos atores sociais, que passam ao largo dos preceitos de racionalização pura e simplesmente. A segunda parte volta-se para a difícil questão religiosa, interna à própria racionalidade científica, com o uso de termos como os de quarentena, mas também externas, através de grupos religiosos que se organizam ativamente para estimular a subversão dos preceitos biomédicos e sociais do isolamento. A terceira parte do artigo, por sua vez, se propõe a pensar três níveis distintos de obstáculos reais para a plena realização das políticas de isolamento social: os níveis político, social e sociológico do problema.

\section{Consenso biomédico e a racionalização da conduta social}

O primeiro aspecto da análise é o que corresponde à tensão entre consenso biomédico e racionalização da conduta social. Existe um tensionamento constante entre, de um lado, um movimento por uma racionalização da conduta social baseado em preceitos das ciências biomédicas, por conta da alta letalidade do vírus, e de outro, determinados tipos de interação, de sociabilidade, ou mesmo, de imaginários que se negam a aderir ao processo. Mas não é só isso. Temos, também, condições sociais concretas que impedem essa plena realização da racionalização da conduta social, como se pode ver em ônibus, metrôs e trens diariamente lotados com trabalhadores precarizados indo e vindo dos seus respectivos postos de trabalho. $\mathrm{O}$ 
mesmo pode ser dito em relação a pequenos e médios comerciantes que relutam, não sem razão, em aderir ao fechamento de suas lojas, com o risco, não menos real, de não conseguirem atingir a meta da renda mensal.

Ora, preceitos de racionalização da conduta chocam-se também com questões de ordem, digamos assim, simbólicas, afetivas ou existenciais. Entre o desejo da ordem e da regularidade, muitos podem optar - se é que podemos falar apenas em "uma opção" -, ainda que com isso arrisquem as suas próprias vidas e a de outros, pelo prazer do acaso, da necessidade de uma vida que precisa ser vivida para além da sobrevivência biológica.

Durante a pandemia, tem havido uma série de tensões, de diferentes ordens e significados. As ações favoráveis aos preceitos de isolamento, mesmo passado mais de um ano desde o início da crise pandêmica, têm adquirido adeptos, em diferentes esferas da vida social e entre os mais diversos atores sociais. Temos as propagandas de instituições governamentais que promovem o isolamento, mesmo no caso daquelas em que suas lideranças políticas teimam em fazer campanhas abertas contra o afastamento social. Temos propagandas de âmbito midiático, da mídia tradicional ao ambiente difuso das redes sociais, com a criação planejada ou espontânea de uma série de slogans favoráveis aos preceitos biomédicos

O mesmo vale no que diz respeito aos círculos de vizinhança, com a constituição de redes de regulação de uma suposta conduta adequada, que vão dos transeuntes nas ruas, até seguranças e trabalhadores do comércio. Recentemente, no caso do Brasil, têm ocorrido grandes manifestações contrárias à gestão do governo federal. Manifestações de âmbito nacional, com maior presença nas capitais, especialmente em São Paulo. Mesmo nesses casos, em que milhares de pessoas saem às ruas em protesto, o estímulo ao cuidado e ao uso correto dos materiais de proteção tem se mantido como um dado relevante, como o uso de máscaras, a higienização das mãos e, no limite, o distanciamento físico - embora este último seja mais difícil de ser feito.

No entanto, simultaneamente, tem havido também uma série de ações contrárias aos preceitos biomédicos, sejam elas voluntárias ou involuntárias, como a ação política negacionista deliberada, ou como aquela desinteressada do engajamento político. Entretanto, o que se tem visto é um conjunto de ações que desafiam os preceitos biomédicos em todos os sentidos e de forma difusa. Elas abarcam diversas modalidades, que vão dos encontros furtivos de ordem familiar, aos encontros mais amplos, em bares e restaurantes; as aglomerações em festas clandestinas com número significativo de pessoas; os shows e espetáculos musicais abertos; a liberação de público em finais de competições esportivas, como se viu na final da Copa Libertadores da América; as festas de final de ano, incluindo natal, ano novo e carnaval, para ficar apenas nos casos brasileiros. 
Em paralelo a esses eventos sociais que envolvem a aglomeração de pessoas, estão também aquelas ações - deliberadas ou não - que cotidianamente desafiam os preceitos biomédicos, como o uso incorreto (ou o não uso) de máscaras faciais em locais públicos, a não higienização das mãos, e no limite, a recusa em tomar a vacina contra Covid-19.

A frequência com que tem se dado ações contrárias às medidas protetivas e racionalcientíficas mostra que existe algo além da mera polarização entre os favoráveis e os contrários a essas mesmas medidas; entre os atentos às necessidades de regulação sanitária mínima, e aqueles que fizeram do negacionismo autoindulgente a sua bandeira política. Em suma, para além ou para aquém, se o quiserem, do debate público sobre o tema, que sempre demarca duas posições facilmente antagonizáveis, há uma miríade de possibilidades que não necessariamente se enquadram nela, ao menos não com facilidade.

Entre as ações favoráveis ao isolamento social e aos demais preceitos biomédicos de combate à pandemia e as ações puramente negacionistas a esses preceitos, certamente estão as questões político-ideológicas características de um país polarizado, como é o Brasil. Mas não apenas isso. Há também aspectos culturais e pessoais, uma série de determinantes concretos, como fatores socioeconômicos e socioeducacionais; isso, sem falar nas questões complexas que envolvem o tensionamento individualidade/coletividade, e o debate filosófico-existencial entre "a defesa irrestrita da vida" e o "direito de viver a vida". Por óbvio, toda análise da adesão/não adesão ao isolamento social e aos preceitos biomédicos que não leve em conta tais questões, acaba por ser uma análise superficial do problema.

\section{$O$ rosto encoberto e o claro-enigma religioso}

Um dos pensadores mais atuantes na reflexão sobre a pandemia, desde o seu início, especialmente a respeito do conjunto de preceitos sociais, políticos e biomédicos, tem sido o filósofo italiano Giorgio Agamben. Há uma série de controvérsias em torno da interpretação de Agamben, com diferentes níveis de recepção crítica. O mesmo pode se dizer em relação a um dos seus últimos textos: "O rosto e a morte". O título refere-se a duas dimensões centrais nos preceitos biomédicos no combate à Covid-19: o uso de máscara, com o encobrimento do rosto em locais públicos, e a interdição da presença de pessoas nos ritos funerários.

O rosto como forma visível, de reconhecimento, pública, como presença, é uma das principais expressões do humano como humano, como existência que nos singulariza em relação a animais não humanos. Ter e portar o rosto como marca da presença de si e do contato com o Outro diferencia de modo decisivo a vida humana em sua especificidade. O mesmo vale para o 
convívio com os mortos, através da participação nos ritos funerários, expressão simbólica do limiar impreciso e demasiado humano entre a vida e a morte. Ora, os preceitos da pandemia exigem tanto o obscurecimento do rosto, com o uso da máscara para impedir o contágio através da respiração, quanto o isolamento do convívio social em todas as instâncias, inclusive os ritos funerários.

Ao lado disso, há um terceiro elemento: a necessidade de isolamento social, com o retiro da vida pública. Assim, há como que latente ao próprio conjunto de preceitos biomédicos e racional-científicos uma moralidade de base religiosa, fundamentada na ideia de retiro, recuo, preparação, higienização, reparo e assim por diante. Mas um retiro cuja promessa de vida futura e renovada parece apontar mais para uma espécie de sociedade dos algoritmos, do que propriamente para algo como uma "humanidade renovada". Mas se há um tom religioso sutil, ou nem tanto, na estruturação dos preceitos de controle do contágio da pandemia, com o uso do termo quarentena, há também entre movimentações religiosas no Brasil, especialmente as de ordem neopentecostal, uma visada bem diferente, aberta e voluntariamente oposta ao isolamento social. Como se pode ver recentemente em mais uma das querelas e impasses da pandemia no país, lideranças evangélicas expressivas e populares tentaram, com a apelação a um ministro do Supremo Tribunal Federal (STF), reabrir as igrejas e, com isso, enfraquecer a política de isolamento.

Nos primeiros dias, quando a decisão monocrática foi imposta, o que se viu foram templos cheios, mostrando uma clara adesão dos fiéis aos movimentos anticientíficos e de fundo irracionalista, ou mais próximos aos impulsos e às paixões de uma vida que deveria ser vivida mesmo com o risco real da morte, por conta da alta letalidade do vírus. Ainda mais recentemente, numa manifestação em favor do negacionismo explícito do governo federal, uma manifestante afirmou, sem pestanejar: "Crente de verdade não tem medo de morrer".

Pode ter parecido estarrecedor para muitos e não sem razão. Ver, de repente, igrejas lotadas, diante do aumento trágico do número de mortos e de hospitalizados. Ainda mais com as cenas pesadas da falta de oxigênio levando pessoas a morrerem por falta de ar no Norte do país. Nada disso, ao que parece, gerou algum tipo de mal-estar, ou serviu como um contraponto que pudesse criar algum cuidado maior entre aquelas pessoas e mesmo em relação às consequências reais das suas ações contrárias às políticas de isolamento. É como se a necessidade religiosa, da interação social de bairro e, não menos importante, da manutenção de um campo de identificação com o conservadorismo moral, colocassem-se numa condição superior não só à manutenção da vida própria, como vida biológica, mas também de uma solidariedade social para além disso. 
Mas não é de todo verdadeiro vincular apenas a um espectro ideológico as ações de não cumprimento do consenso biomédico. Não à toa passou a ser frequente, nas redes sociais, a apresentação de contradições entre os que se colocavam na condição de vigilância moral do isolamento social e que, no entanto, também participavam de vários tipos de aglomeração. Os casos foram e têm sido muito variados. Lideranças políticas, influenciadores digitais, militantes partidários, entre tantos outros. Aparições em festas clandestinas, comemorações de natal, ano novo, carnaval, viagens com grupos de amigos e assim por diante.

\section{Confinamento e lockdown: as faces ausentes de duas ciências}

A sociologia do conhecimento científico ou os "Social Science Studies", em um de seus ramos de investigação, tem as "controvérsias científicas"1 como objeto privilegiado de investigação. É sabido que as pesquisas de controvérsias científicas, das mais diferentes áreas do conhecimento científico disciplinar, têm sido problematizadas e divulgadas em centenas de publicações, em todo o mundo, desde a década de 1980. Entretanto, a recomendação biomédica da prática do distanciamento social e mesmo do lockdown não se constituem, em nosso entender, um caso típico (ou clássico) de uma controvérsia científica, mas sim um caso que, dada a sua complexidade, exigiria um tratamento distinto daquele que foi (e tem sido) dado.

De certo modo, a problematização que realizamos até então neste artigo fez transparecer, cremos, que esta questão do distanciamento social - que envolve de fato racionalidades particularizadas, diferenciadas dentro da prática da própria Ciência -, traz em sua forma menos revelada, em suas dimensões mais rizomáticas ou radiculares, uma complexidade não tão aparente, tanto no âmbito da Ciência, como como no âmbito do político ${ }^{2}$ e do social. É neste sentido que afirmamos que o distanciamento social e mesmo o lockdown, considerando o debate que se instaurou na grande mídia, não pode, por um lado, ser tratado como uma controvérsia científica, posto que no âmbito da ciência biomédica é uma perspectiva majoritária; tampouco pode, por outro lado, ser ignorado e relegado pelas demais ciências exclusivamente à biomedicina.

\footnotetext{
${ }^{1}$ Referimo-nos a trabalhos tais como: Barnes (1982); Bloor (1984); Collins (1983); Knorr Cetina (1981; 1981b); Knorr Cetina e Mulkay (1983); Latour e Woolgar (1986); Pinch (1983), para citar apenas alguns dos precursores.

${ }^{2}$ Ao nos referirmos ao termo "o político", seguimos a distinção que Chantal Mouffe faz, em sua obra "En torno a lo político" (2007:15-6). Para essa cientista política, existe uma distinção importante entre os conceitos "a política" e "o político"; diz ela: “[...] tomando o vocabulário de Heidegger, a política refere-se ao 'ôntico', enquanto que 'o político' tem a ver com o nível ontológico [...]. Concebo 'o político' como a dimensão de antagonismo que considero constitutiva das sociedades humanas, enquanto que entendo 'a política' como o conjunto de práticas e instituições através das quais se crê em uma determinada ordem organizando a coexistência humana em contexto de conflitividade derivada do político" (2007:15-6). Atribuímos ao termo "o social" uma perspectiva muito semelhante e por isto trazemos à luz o conceito "onto-epistemológico".
} 
O uso do distanciamento social como medida para tentar conter o avanço de epidemias não é algo novo, pelo contrário, é uma prática que está presente há muito na história da humanidade. Vale lembrar, nesse sentido, que o isolamento de enfermos com doença contagiosa fora mencionado já no Antigo Testamento, no livro de Números, capítulo 5: "E falou o Senhor a Moisés, dizendo: ordena aos filhos de Israel que lancem fora do arraial a todo o leproso [...] para que não contaminem os seus arraiais, no meio dos quais eu habito. E os filhos de Israel fizeram assim, e os lançaram fora do arraial [...]”. Segundo o historiador Alexandre Carvalho (2020), a lepra - conhecida hoje como hanseníase - foi a primeira doença para a qual foi imposto o isolamento dos infectados. Por se tratar de uma doença incurável à época, e que deixava o doente desfigurado nos casos mais graves, os doentes acabavam sendo isolados do convívio social, muitas vezes de forma violenta - embora o risco de contágio fosse relativamente baixo (Carvalho, 2020). Vem justamente daí toda a carga pejorativa e preconceituosa que o termo leproso carrega ainda hoje, fazendo referência a alguém doente, contagioso, cujo contato social precisa ser evitado a todo custo.

Mas é preciso mencionar que a primeira grande experiência com a adoção do isolamento social como medida de saúde pública para conter o avanço de uma epidemia ocorreu na Idade Média, durante a epidemia da peste bubônica, que teve início no final da década de 1340. A Peste Negra, como popularmente ficou conhecida, vitimou - segundo estimativas - entre um terço a metade da população europeia. Como destaca Neto (2020), embora a medicina da época pouco ou nada conhecesse sobre micro-organismos causadores de doenças, bem como ainda não soubesse o papel epidemiológico central que os ratos e as pulgas tiveram na propagação da peste, logo se percebeu que a transmissão dava-se pelo contato com os doentes. Com efeito, o pânico causado pela situação levou as autoridades públicas a adotarem medidas extremas, como o exílio dos infectados fora dos limites das cidades, até a sua recuperação, ou então, sua morte. Em 1377, o porto de Ragusa, atual cidade de Dubrovnik, na Croácia, mas que na época pertencia à Veneza, determinou que os tripulantes e os objetos que chegavam nos navios deveriam ficar em isolamento durante trinta dias (uma trentina) antes de poderem desembarcar; posteriormente, o prazo foi aumentado para quarenta dias, uma quarenta, medida que foi adotada por outras cidades (Neto, 2020). A palavra "quarentena", portanto, tão utilizada nos dias de hoje, tem origem italiana e deriva justamente de Veneza. Como destacou o poeta florentino Giovanni Boccaccio, que vivenciou com seus próprios olhos a pandemia da peste bubônica, narrando-a de forma brilhante em sua obra Decameron, aqueles foram tempos sombrios tão assustadores que as pessoas acabaram se privando daquilo que nos faz humanos por essência, isto é, o contato social: "um irmão abandonou o outro, e o tio o sobrinho, e a irmã o irmão, e muitas vezes a mulher o 
seu marido; e (o que é pior e quase não acreditável) os pais e as mães os filhos" (Boccaccio, [1352] 2004).

Desde então, a quarentena tornou-se uma das principais medidas sanitárias adotadas ao redor do planeta pelas autoridades públicas para controlar a propagação de doenças contagiosas. $\mathrm{O}$ que se deve destacar aqui, no entanto, é que quando falamos em quarentena, estamos nos referindo especificamente ao isolamento de indivíduos infectados, mas não dos saudáveis. Essa precisão conceitual é importante de ser feita, pois no caso específico da Covid-19, a quarentena foi uma dentre as diferentes medidas de distanciamento social muito mais amplas adotadas pelos países na tentativa de conter o avanço do coronavírus.

Como mencionamos, um dos pontos centrais com relação ao distanciamento social ou sua radicalização, o confinamento residencial conhecido e popularizado pelo eufêmico estrangeirismo lockdown, tem sido o de se fazer uma análise mais próxima da tensão entre o consenso biomédico e a racionalização da conduta social. Entretanto tal análise (ou reflexão) não pode passar ao largo de duas ciências, ou áreas do conhecimento científico, isto é, a biomedicina e as ciências da sociedade, voltadas para o objeto central deste artigo, que tem sido a problematização do distanciamento social/confinamento à luz de uma perspectiva ontoepistemológica.

Parece não restar qualquer dúvida no âmbito do conhecimento científico médico e, mais amplamente, biomédico, que tanto o distanciamento social, como o lockdown são eficazes (em algum nível) contra a propagação do Sars-Cov-2. Uma das primeiras descobertas feitas pela ciência no combate à Covid-19 foi o fato de que a grande maioria das pessoas infectadas por esse vírus são assintomáticas, ou então desenvolvem sintomas leves, muito semelhantes aos de um resfriado comum. Todavia, isso não impede essas pessoas de transmitirem o vírus a outras que, por sua vez, poderão desenvolver sintomas graves da doença e até mesmo vir a óbito. Consequentemente, logo ficou claro que adotar a quarentena, isto é, apenas o isolamento dos doentes, não era o suficiente para conter a disseminação do vírus e evitar o avanço da pandemia, sobretudo em locais onde o vírus já havia se espalhado para várias regiões: era necessário um distanciamento social muito maior e mais rígido, tanto dos infectados quanto daqueles que não foram contaminados pelo vírus.

A racionalidade por trás dessa abordagem biomédica é relativamente simples, e amparase na perspectiva lógico-epistemológica de orientação analítica, muito empregada por diversos modelos científicos amplamente aceitos, qual seja: o vírus, um patógeno, necessita parasitar células humanas para garantir a sua "vida" causando, assim, a doença de seu hospedeiro, podendo leva-lo à morte; a curva de "vida" do vírus (ontogenia) em seu hospedeiro é de 
aproximadamente duas semanas. Tais premissas implicarão em pelo menos dois desfechos possíveis: a) o vírus reproduz-se no hospedeiro humano e espalha-se para fora infectando outros corpos humanos; b) o vírus permanece no hospedeiro (isolado) e sem a possibilidade de se espalhar, extinguindo-se, seja combatido pelos anticorpos desenvolvidos pelo hospedeiro ou mesmo pela morte deste. Como existem humanos "sadios" contaminados, os chamados assintomáticos e, como já mencionamos, isolar somente os (perceptivelmente) doentes não assegura a intrasmissibilidade, logo, com o isolamento de todos os possíveis "hospedeiroshumanos" a propagação do agente patogênico indubitavelmente ficará interrompida e o mesmo terá sua "espécie" extinta (ou quase extinta, considerando que o vírus pode também parasitar outros organismos vivos não humanos) em talvez pouco menos de um mês. Este é um dos princípios mais elementares da infectologia, mesmo para doenças menos graves. O que temos aí, do ponto de vista epistemológico, é chamado de "Realismo Epistemológico", em que são identificadas cadeias de relações causais que, quando interrompidas, cessam seus efeitos.

Tomemos, então, conforme demonstramos acima, o "teorema biomédico"”3: se todos os hospedeiros humanos do Sars-Cov-2 ficarem isolados (confinados) ou em pequenos grupos familiares, por um período de aproximadamente duas semanas, a impossibilidade de transmissão levaria a população viral a rápido colapso (declínio) e até mesmo à extinção do vírus e, consequentemente, da doença pandêmica Covid-19 em humanos. A pergunta que fica e que não tem sido respondida satisfatoriamente até então, é a seguinte: por que esse teorema, mais especificamente da infectologia, não foi aplicado a todas as sociedades humanas e, quando aplicado, com raras exceções, os resultados não foram suficientemente satisfatórios? ${ }^{4}$

Certamente que entender comparativamente o emprego e a eficiência do distanciamento social e mesmo do lockdown em diferentes sociedades de distintos países e regiões do planeta requer um trabalho minucioso, de longo prazo e transdisciplinar. Certamente muitas pesquisas nessa direção já estão em andamento. Esse tipo de pesquisa, diríamos praticamente um inquérito de proporções globais, para de fato lançar boas luzes à pergunta por nós formulada, teria de considerar uma série de variáveis relevantes, atinentes a diferentes disciplinas do conhecimento científico, que levasse em conta dimensões múltiplas da realidade social de cada país ou região,

\footnotetext{
${ }^{1}$ Chamamos assim, posto que teorema é qualquer preposição demonstrável logicamente (Abbagnano, 2003:951).

${ }^{4}$ Aqui cabe um esclarecimento e uma tomada de posição que julgamos necessária para podermos avançar com o nosso argumento que é, diríamos, onto-epistemológico e transdisciplinar: os autores deste artigo creem que o modelo (ou o teorema) biomédico, do modo como está formulado acima, teoricamente funciona para a pandemia de Sars-Cov-2, e mais, o mesmo modelo tem funcionado para evitar outras pandemias. Portanto, não se trata de qualquer "negacionismo", termo muito em moda e que tem bloqueado discussões de caráter mais científico. Evidentemente que um confinamento mais longo é de fato um "luxo" para poucos no Brasil e no mundo, com danos a diferentes subsistemas sociais da sociedade como um todo. Sobre isto, ver Rodrigues e Costa (2021).
} 
tais como: aspectos culturais, religiosos, regimes políticos, liberdade de imprensa ${ }^{5}$, liberdades individuais, confiabilidade censitária, nível de escolaridade, renda per capita, IDH, apenas para citar algumas. Indubitavelmente este tipo de pesquisa, de modos distintos (e parciais), já vem sendo realizado por diferentes centros de pesquisa internacionais.

Por certo que levará muito tempo para que se consiga estabelecer parâmetros seguros, verossímeis e confiáveis que avaliem o grau de eficiência e eficácia dos diversos esforços internacionais de distanciamento, isolamento e confinamento sociais. Entretanto, se é verdadeira a perspectiva biomédica - e cremos que sim - de que o confinamento radical por período compatível com a curva ontogênica do vírus teria dado outro rumo à pandemia, não obstante às variáveis como as elencadas acima, a pergunta persiste: por que a pandemia apresentou (ou tem apresentado) o desfecho que teve em diversos países, independentemente, das variáveis anteriormente mencionadas?

É neste ponto que gostaríamos de levantar uma hipótese aos dois questionamentos (corolários) anteriormente feitos. Antes, porém, queremos destacar que nossa hipótese considerando que toda a hipótese se constitui em uma resposta a priori a questionamentos científicos - foi estabelecida a partir dos seguintes pressupostos:

a) Correção e razoabilidade epistemológica do "teorema biomédico", na nossa opinião;

b) Embora correto epistemologicamente, o "teorema biomédico" e sua ampla recomendação - e adoção - internacional, não logrou o êxito que pretendia, ou prometia.

Hipótese: Do ponto de vista das ciências biomédicas, o "Teorema do isolamento/ confinamento social" não apenas está teoricamente correto como pode, na prática, funcionar. Entretanto, o que está sendo preconizado às sociedades humanas pelas ciências biomédicas não levou em conta a imperiosa necessidade subjetiva da vida gregária, grupal, social dos humanos, tão avassaladora e dinâmica quanto as necessidades fisiológicas e psicológicas, em que muitas das vezes a própria "vida orgânica" é consciente ou inconscientemente colocada em risco em detrimento dessa pulsão, desse impulso ou subjetividade psicossocial.

Ao comentar a hipótese, trazendo elementos adicionais de forma mais livre a sua estrutura, somos da opinião de que boa parte do insucesso do distanciamento social, e mesmo de um lockdown, preceituado enfaticamente pela área biomédica, logrou (e tem logrado) um

\footnotetext{
${ }^{5}$ A China, por exemplo, segundo o "Repórteres Sem Fronteiras", em sua "Classificação Mundial da Liberdade de Imprensa - 2021”, dos 180 países pesquisados, ocupa a posição 177, ganhando apenas do Turcomenistão (178), da Coreia do Norte (179) e do desconhecido país africano, fronteiriço à Etiópia, chamado Eritréia (180). Disponível em https://rsf.org/pt/classificacao\%20?\#. Acesso em 12 jun. 2021.
} 
sucesso pífio (pelo menos em países não autoritários). Esse relativo fracasso de um "remédio" importante, não aconteceu porque as pessoas não sejam razoáveis ou sejam desinformadas como, de certo modo quis fazer parecer parte da mídia internacional e brasileira - no último caso, com importantes exceções, uma mídia militante e, por vezes, parecendo obtusa e inculta. O insucesso deveu-se, entre outras coisas, à falta de percepção de que uma pandemia de tão amplo alcance, com níveis importantes de transmissão e de letalidade iria necessariamente afetar diferentes sistemas da sociedade, tais como o social, o cultural, o político, o econômico, o educacional, dentre outros, e isto demandaria, sem dúvida, esforços transdisciplinares. Há mais de um ano alertávamos para essa mesma questão:

[...] quando observamos as medidas de distanciamento social, não podemos perder de vista que algumas culturas, como a brasileira e mesmo as latino-americanas, por exemplo, apresentam maior proximidade entres as pessoas (...) de forma absolutamente involuntária. Como se sabe, cultura é uma dimensão profundamente introjetada, e quando exteriorizada, se faz de forma automática, não refletida, conforme nos mostra o próprio conceito de habitus de Pierre Bourdieu (1989), e muitos dos estudos culturais. Portanto, o sistema cultural é uma dimensão importante a ser considerada na eficácia do distanciamento social em determinadas regiões, isto é, na adesão ou não por parte da população (Rodrigues; Costa, 2021:324-5). ${ }^{6}$

O renomado historiador de Oxford, hoje professor da Universidade hebraica de Jerusalém, Yuval Noah Harari (2017), em sua obra "Sapiens", ao falar da Revolução Cognitiva que aconteceu como o Homo sapiens, por volta de 70 mil anos atrás, afirma que a partir de então o sapiens desenvolveu a capacidade de viver em uma "realidade dual [...] por um lado, a realidade objetiva dos rios, das árvores e dos leões; por outro, a realidade imaginada de deuses, nações e cooperações" (2017:41). Harari mostra-nos que essa mudança - chamada pelo autor de "Revolução Cognitiva" - permitiu aos humanos "superar o genoma", dando-lhes a capacidade de criar uma "realidade imaginada com palavras [que] possibilitou que um grande número de estranhos coopere de maneira eficaz" (Ibid:41). Afirma ainda que por causa da Revolução Cognitiva, o Homo sapiens conseguiu revisar seu comportamento de acordo com as necessidades e transformações do seu ambiente (objetivo e/ou subjetivo) e que foi "isto que abriu uma via expressa de evolução cultural, contornando engarrafamentos da evolução genética" (p. 41). O autor ainda acrescenta que:

A imensa diversidade de realidades imaginadas que os sapiens inventaram e a diversidade resultante de padrões de comportamento são os principais componentes do que chamamos de "culturas". Desde que apareceram, as culturas nunca cessaram de se transformar e se desenvolver e essas alterações irrefreáveis são o que denominamos de "história" [...]. A Revolução Cognitiva é, portanto o ponto em que a história declarou

\footnotetext{
${ }^{6} \mathrm{O}$ artigo aqui citado, publicado na revista "Sociologias" - PPGS/UFRGS, uma das revistas de maior prestígio no país, foi escrito pelo menos um ano antes da sua publicação (enviado à "Sociologias", conforme referência do próprio Editor, em 11.05.2020), demora, essa, "praxe" em periódicos considerados de excelência. Esperamos que, pós-pandemia, esses prazos possam ser revistos, para maior eficácia do próprio sistema científico em sociologia
} 
independência da Biologia [...]. Para entender a ascensão do cristianismo ou a Revolução Francesa, não basta compreender a interação entre genes, hormônios $e$ organismos. É necessário também levar em consideração a interação entre ideias, imagens e fantasias (Harari, 2017:46 [grifos nossos]).

É contundente a fala de Harari, sobretudo no trecho por nós grifado, que vem ao encontro de um dos aspectos centrais que perpassa todo este artigo, coadunando-se, inclusive, com a hipótese que levantamos. Assim, reafirmamos nossa hipótese, mas desta vez expondo-a em forma de tese:

Tese: Não é possível impor uma "tecnologia", produzida pela ciência biomédica (ou qualquer outro ramo do conhecimento científico), quando essa tecnologia implica em (ou sua aplicação demanda de) fatores comportamentais de massa, independentemente de premissas normativas ou éticas.

Quem acompanhou o desenvolvimento da pandemia através da grande mídia, desde seu início $^{8}$, certamente não deixou de notar que nas entrevistas feitas pelos jornalistas, em diferentes programas, mas sobretudo nos telejornais, os entrevistados eram quase que exclusivamente pertencentes às ciências biomédicas - o restante eram economistas, mormente com vieses econométricos. Embora estivesse sendo proposto como "remédio" à pandemia o distanciamento/confinamento social, remédio esse que demandava fundamentalmente atitudes comportamentais de massas, nem os infectologistas (em sua maioria), tampouco os jornalistas, pareceram ter se dado conta de que o fenômeno pandêmico não era um problema exclusivamente orgânico, biomédico, mas uma questão que afetava diretamente o social, as pessoas, as culturas, as massas e que para seu sucesso era necessária a coadjuvancia de outras áreas do conhecimento. Por conseguinte, a preconização de uma conduta social estribada em preceitos das ciências biomédicas, requer necessariamente o apoio para a sua implementação de uma perspectiva sociológica, posto que se tratam de vieses tanto epistemológicos, como ontológicos. Os estudos das sociedades, desde Aristóteles passando pelos clássicos fundadores da sociologia, têm demonstrado a imperiosa necessidade subjetiva, gregária, grupal, representacional e social dos humanos - dos Sapiens, como se refere Harari. Necessidade essa tão imperiosa quanto as necessidades orgânicas, fisiológicas e psicológicas, como já mencionamos.

Estar juntos é uma dimensão constitutiva da própria condição social da vida humana. Em grande medida, o Homo sapiens é o Homo socius. A socialização e humanização do homem são coetâneas, partem do mesmo processo; poderíamos dizer, do processo de subjetivação propiciado pela (r)evolução cognitiva. O que a pandemia vem mostrando de forma cada vez mais evidente é que a necessidade de interação, associação, agrupamento, em suma, participação em atividades

\footnotetext{
${ }^{7}$ Estamos utilizando o termo tecnologia como todo e qualquer produto produzido pela ciência e aplicável às sociedades. Devemos lembrar que, por certo, tanto o soro caseiro, como a pílula anticoncepcional ou mesmo os antidepressivos utilizados massivamente são tecnologias de uso social e massivo.

${ }^{8}$ Recomendamos ver: Rodrigues, Costa e Guedes (2020); Lacerda (2020); Rodrigues (2020).
} 
sociais de diferentes níveis e feições é uma das principais forças que constroem o "cimento social" ou os laços sociais; mais que isto, constitui o próprio fenômeno social, ou seja, a Sociedade. Suspender a interação social em sociedades livres, ou seja, sem o uso da força, seria o mesmo, mutatis mutandis, que exigir que um organismo biológico, para continuar existindo, tivesse de abrir mão de seu próprio corpo. Portanto, esse discernimento aqui é fundamental e é parte (ou deveria sê-lo) do ofício do sociólogo. Não se pode homogeneizar o conjunto de necessidades de ordem social com o infantilizante termo "aglomeração", usado muitas vezes em tom acusatório e moralizante, como se o anseio legítimo pela interação social - o que nos constrói como Sociedade e é imanente ao "ser-social" - fosse expressão de estupidez, irresponsabilidade moral e má-intenção política.

As ciências sociais, em geral, e a sociologia, em particular, não foram ouvidas; tampouco elas se fizeram ouvir. A sociologia como ciência (e os sociólogos, por certo) custou a acordar ${ }^{9}$ ! Fetichezada nos imbróglios político-militantes, esqueceu-se de "fazer ciência" e parear a ciência da sociedade às ciências biomédicas na busca de soluções eficazes, inclusive para que o distanciamento/confinamento social - o qual teve amplo apoio e adesão dos sociólogos e de suas entidades de classe - lograsse efetivo êxito. Hartmut Rosa (2020), em instigante artigo, vai nessa mesma linha crítica à sociologia como ciência. Diz ele:

Os sociólogos reinterpretam com instrumentos científico-sociais uma auto interpretação da sociedade que se tem coagulado como realidade institucional. Sua tarefa é sugerir respostas para um "best account", ou seja, para a melhor interpretação possível da situação social em um momento histórico determinado (Rosa, 2020: 27[grifos nossos]).

Se por um lado têm existido grupos políticos articulados com o intuito de sabotar as recomendações de isolamento/confinamento social, sendo isto um fato; por outro lado, há uma real dificuldade de implementação do distanciamento, dada a própria condição social da vida humana, do desejo de interação; mais que isto, da necessidade de contato pessoal e de participação e pertencimento a agrupamentos sociais de diferentes naturezas, como destacamos já fartamente. Não poderiam (deveriam) as ciências da sociedade ter assumido uma postura mais tecnicamente proativa para a efetivação, no ceio social - seu objeto de conhecimento por excelência -, do "remédio" proposto pela área biomédica, com o qual ela majoritariamente (e explicitamente) concordava? Parece que a sociologia está se desacostumando a fazer ciência! O que em si é uma contradição! Os cientistas sociais parecem ter caído na armadilha, justamente por deixarem de lado a sua ciência, ao assumirem o polo antagônico do "negacionismomilitante" com a "militância-afirmacionista", quando, em verdade, deveriam simplesmente ter

\footnotetext{
${ }^{9}$ A Simbiótica (2020, número especial), vale destacar, foi corajosamente uma das revistas de divulgação científica nas ciências sociais pioneira na formulação de um dossiê que ajudasse a enfrentar as necessárias reflexões teóricoepistemológicas e ensaios empíricos, transdisciplinares, sobre a pandemia.
} 
feito ciência, ciência tão necessária para a sociedade. Neste aspecto, não podemos deixar de nos socorrer novamente à perspectiva de Rosa (2020:28), a qual harmoniza-se com a nossa própria perspectiva, qual seja:

Para desenvolver um 'best account' (sempre transitório) da crise atual, é preciso responder a duas perguntas fundamentais: (a) para onde deve olhar a sociologia para entender a dinâmica que se está desenvolvendo? (b) (Como) pode ajudar aos atores sociais a encontrar uma saída criativa à crise? Pode e deve posicionar-se normativamente à luz das alternativas possíveis?

\section{Considerações}

A dificuldade encontrada pelos países com regimes políticos não autoritários, como o Brasil, em controlar o avanço da pandemia de Covid-19, e principalmente, fazer a população aderir aos preceitos biomédicos, em especial, o distanciamento social e o lockdown é uma questão altamente complexa. Tal problemática está muito além do mero debate políticoideológico entre, de um lado, grupos "afirmacionistas" e "progressistas", baluartes da ciência e dos preceitos biomédicos, defensores do isolamento social; e de outro, grupos "negacionistas" e "conservadores", que dentro de sua suposta irracionalidade, negam a gravidade da situação. Embora esses dois grupos existam e façam muito barulho, seja na mídia, nas redes sociais, ou até mesmo nas ruas, a problemática em torno do isolamento social e do combate à pandemia, como procuramos demonstrar ao longo deste artigo, é muito mais profunda que a simples polarização; ela envolve uma série de questões de natureza cultural, concreto-social, factual, simbólica, filosófica.

Assim, se por um lado o argumento da ciência biomédica - o de que evitar o contato social entre os humanos impede ou ao menos reduz a disseminação da Covid-19 - se sustente do ponto de vista teorético e epistemológico, dada, por óbvio, a natureza viral da doença, por outro lado, está o fato de que nós, humanos, somos seres essencialmente sociais. Foi justamente a vida em agrupamentos sociais que levou à revolução cognitiva que resultou no Homo sapiens. Como afirmamos, somos Homo socius; a vida em sociedade está no cerne da nossa existência. E, obviamente, toda tentativa de mudar o comportamento de massa, de evitar o contato social entre os indivíduos, não ocorrerá sem resistências. A sociologia, ciência cujo objeto de estudo é precisamente o social, deveria ter se dado conta disso. Ao invés de ter se atrincheirado, ao lado dos infectologistas, na defesa irrestrita ao isolamento social, os sociólogos deveriam ter mobilizado todo o vasto e rico arcabouço teórico-metodológico das ciências sociais para tentar explicar os motivos de tamanha resistência por parte de uma parcela significativa da população em seguir os preceitos biomédicos; poderia buscar compreender também os tensionamentos entre 
grupos "pró-defesa da vida" e "pró-defesa do direito de viver"; a violência simbólica causada por uma mudança tão brusca na conduta social dos indivíduos; ou ainda, os aspectos concretofactuais que impedem a adoção homogênea de medidas de controle da pandemia em um país continental e de tantos contrastes regionais e culturais, como é o Brasil. Enfim, a sociologia, como campo do conhecimento científico, tem muito a dizer - se for ouvida e se fizer ouvir.

\section{Referências}

ABBAGNANO, Nicola (2003), Dicionário de filosofia. São Paulo, Martins Fontes.

BARNES, Barry (1982, Kuhn and social science. Londres, The Macmillan Press Ltd.

BLOOR, David (1984), Contemporary perspective on the sociology of knowledge. Londres, New Brunswick.

BOCCACCIO, Giovanni (2004), Decameron. Firenze: Le Monnier [Consult. 15-05-2021]. Disponível em http://www.dominiopublico.gov.br/download/texto/lb000120.pdf

CARVALHO, Carvalho (2020). "Dias de solidão: quando surgiu o isolamento social?" Aventuras na História, 11 de julho de 2020 [Consult. 15-05-2021]. Disponível em https://aventurasnahistoria.uol.com.br/noticias/reportagem/dias-de-solidao-quando-surgiu-oisolamento-social.phtml

COLLINS, Randall (1983), "An empirical relativist program in the sociology of scientific knowledge", in K. Knorr-Cetina, M. Mulkay (Eds.). Science Observed - Perspectives on the Social Study of Science. Beverly Hills, Sage Publications, pp. 85-113.

HARARI, Yuval Noah (2017), Uma breve história da humanidade. Sapiens. Ed. Porto Alegre, L\&PM.

KNORR CETINA, Karin; MULKAY, Michael (Eds.) (1983), Science observed - perspective on the social study of science. Beverly Hills, Sage Publications.

KNORR CETINA, Karin (1981), "Social and scientific method or what do we make of the distinction between the natural and social science?". Humanities in Society, California, v. 11, n. 2, pp. 335-59.

KNORR CETINA, Karin (1981b, The manufecture of knowledge: an essay on the construtivist and contextual nature of science. Oxford, Pergamon Press.

LACERDA, Marcos (2020), "Governança na pandemia: aciência como regulação moral e os problemas da biopolítica”. Simbiótica. Edição Especial, v. 7, n.1, pp.69-86 [Consult. 15-05-2021]. Disponível em https://periodicos.ufes.br/index.php/simbiotica/article/view/30983

LATOUR, Bruno; WOOLGAR, Steve (1986), Laboratory life: the construction of scientific facts. New Jersey, Princeton University Press.

PINCH, Trevor (1983), "Towards an analysis of scientific observation: the externality and evidential significance of observational reports in physics". Social Studies of Science, v. 15, n. 1, pp. 3-36.

MEYERS, Steven Lee et al. "Power, Patriotism and 1.4 Billion People: How China Beat the Virus and Roared Back". The New York Times, 5 de fevereiro de 2021. [Consult. 15-05-2021]. Disponível em https://www.nytimes.com/2021/02/05/world/asia/china-covid-economy.html. 
NETO, Benedito (2020), "Em tempos de quarentena, uma busca de sua origem”. Enfermagem Brasil, São Paulo, v. 19, n. 2, pp. 96-7.

REPÓRTERES SEM FRONTEIRAS (2021), Classificação Mundial da Liberdade de Imprensa - 2021. [Consult. 12-06-2021]. Disponível em https://rsf.org/pt/classificacao\%20?\#

RODRIGUES, Léo P.; COSTA, Everton G. da. (2021), "Impacto da pandemia de Covid-19 ao sistema social e seus subsistemas: reflexões a partir da teoria social de Niklas Luhmann". Sociologias, ano 23, n. 56, pp. 302-35 [Consult. 15-06-2021]. Disponível em https://doi.org/10.1590/15174522-102859

RODRIGUES, Léo P.; COSTA, Everton G. da; GUEDES, Eduardo (Orgs.). (2020). "Em tempos de pandemia: para um pós-epidêmico como oportunidade virtuosa". Simbiótica. Edição Especial, v. 7, n.1 [Consult. 16-06-2021]. Disponível em https://periodicos.ufes.br/simbiotica/issue/view/1191

RODRIGUES, Léo P. (2020), "A controvérsia científica em torno da cloroquina e hidroxicloroquina no tratamento da Covid-19: a importância dos estudos sociais da ciência na sociedade complexa". Simbiótica. Edição Especial, v. 7, n. 1, pp. 147-71 [Consult. 15-05-2021]. Disponível em https://periodicos.ufes.br/simbiotica/article/view/30988

ROSA, Hartmut (2020), "La sociedad ante la desaceleración forzada. Una interpretación sociológica de la crísis del Coronavirus. Diferencia(s)". Revista de Teoría Social Contemporánea, Buenos Aires, n. 11, pp. 19-32. 


\begin{abstract}
Parallel to the millions of lives that it killed across the planet and the various consequences brought to different spheres of social life, the Covid-19 pandemic also brought to light a series of debates of a moral, ideological, cultural and social order. Biomedical guidelines to try to contain the advance of the coronavirus, especially social isolation, created great tension around some highly complex issues, such as between the commitment to the collectivity versus individual freedom, the right to live life versus the unrestricted defense of life, economic needs versus maintaining health. The purpose of this article was precisely to reflect on these issues, seeking to problematize the place of Sociology - as a field of scientific knowledge - within this debate.
\end{abstract}

Keywords: Covid-19 pandemic; social isolation; science; sociology.

\title{
Resumen
}

Paralelamente a los millones de vidas que mató en todo el planeta y las innumerables consecuencias que trajo a diferentes ámbitos de la vida social, la pandemia Covid-19 también sacó a la luz una serie de debates de orden moral, ideológico, cultural y social. Las pautas biomédicas para intentar contener el avance del coronavirus, especialmente el aislamiento social, generaron gran tensión en torno a algunos temas de alta complejidad, como entre el compromiso con la colectividad versus la libertad individual, el derecho a vivir la vida versus la defensa irrestricta de la vida, las necesidades económicas versus la mantención de la salud. El propósito de este artículo fue precisamente reflexionar sobre estos temas, buscando problematizar el lugar de la Sociología - como campo del conocimiento científico - dentro de este debate.

Palabras-clave: pandemia de Covid-19; aislamiento social; ciencia; sociología. 